The end of the XX century is characterized by uncertainty of the past, present and future. In these conditions, the culture was left in limbo with a sense of its worthlessness and inevitable death.

As a complex phenomenon, postmodernism, as defined by J. F. Lyotard, is an "uncontrolled increase in complexity".

Postmodernism according to Z. Bauman- " this is modernism that has admitted its defeat and its impossibility, which requires significant adjustments»

$$
* * *
$$

1. Bauman, Z. Philosophy and postmodern sociology. Postmodernism and culture. [Text] / Z. Bauman // Question of philosophy. - 1993. - №3. - P. 46-61.

2. Genis, A. the tower of Babel: Art of the present time [Text] / A. Genis // Foreign literature. - 1996. - № 9. - 253S.

3. Graham Gordon Philosophy of art [Text]: introduction to aesthetics / Gordon Graham; [translated from English by M. O. Vasiliev]. - Moscow: Slovo, 2004. - 251, [1] p.: ill.; 21 cm. - (Big library "Slovo"). Bibliogr.: pp. 247-249. - Edict. - TRANS. view. : Philosophy of arts / Gordon Graham. - 1997. - ISBN 585050-733-7

\title{
Afanasieva T.Yu. \\ Language competence as one of the aspects of forming students ' readiness for intercultural communication
}

Belgorod state Institute of arts and culture

(Russia, Belgorod)

doi: $10.18411 / l j-08-2020-108$

idsp: ljournal-08-2020-108

\section{Abstract}

The Educational potential of the discipline "foreign language" in the formation of readiness for intercultural communication it is Known that the system of teaching a foreign language is determined primarily by social and economic factors. Political, socio-economic and cultural changes in Russia in the 90s significantly expanded the functions of a foreign language as a subject.

The modern system of teaching a foreign language is characterized by the fact that, first, practical knowledge of a foreign language has become an urgent need for broad segments of society and, second, General social contact creates favorable conditions for differentiation of foreign language teaching. The new socio-economic political situation requires the implementation of a policy in the field of foreign language education in society, aimed at meeting both public and personal needs in relation to foreign languages. The specificity of the subject of a foreign language is the orientation of the educational process to the personality of the student, the determinant of which in a certain sense is the language personality. As we have already noted, the concept of a secondary language personality - as a total verbal and semantic entity-is specific to a foreign language as an academic subject. To achieve the final result, it is necessary to master not only the appropriate foreign-language "technique", but also to learn a huge amount of extra-linguistic information necessary for adequate communication and mutual understanding at the intercultural level, as well as the development of such qualities that allow a person to communicate with representatives of other cultures. Therefore, the acquisition of a foreign language should be intertwined with the General ability to communicate in this language, its (communication) affective and cognitive aspects. It is, first, about the organization of communication at the intercultural level (in a broad cultural aspect) and, secondly, about the development of the student's needs and ability to participate in it. The result of this should be formed in the student's secondary language personality traits of a certain level, allowing him to participate in cross-cultural 
communication and self-improvement in the activities mastered by him. The purpose of studying a foreign language was "practical mastery of a foreign language". Consider the very concept of "practical mastery". Over the past thirty years, the practical goals of teaching the subject were understood as: "mastering speech within a certain framework"; " formation of skills and abilities to understand the thoughts of other people (in oral and written forms) and Express their thoughts (also in oral and written forms)"; "development of speech skills in all types of speech activity"; "teaching communication in a foreign language in the unity of all its functions: cognitive, regulatory, value-orientation, and label". In our opinion, the General tendency to put forward the development of communication skills in a foreign language as the goal of training is positive. However, the tasks of teaching a foreign language are broader than just practical mastering of foreign language communication. Other important tasks related to the acquisition of knowledge about the language and, through the language, the culture of the people concerned should also be in view. In the process of forming a language personality, what is the purpose of training,

It should be noted that the implementation of comprehensive planning of the tasks of teaching, upbringing and development of students in the process of learning a foreign language is very difficult. This is because the Declaration a practical purpose as a leader translates the three other goals in the category of minor. The result is an excessive "pursuit" of stable speech skills and abilities at the expense of developing, educational and educational aspects of learning..

The modern interpretation of practical foreign language proficiency is primarily related to the possibility of real access to a different culture and its representatives. The importance of the pragmatic aspects of studying the subject increases along with the need for language as a means of communication, so it is necessary to study the needs of students in a particular language, as well as find a way to real communication and possible real language contacts at home and abroad. It is in these conditions that a foreign language can acquire all the possible characteristics of a second language and the process of controlled language acquisition in isolation from the country of the language being studied approaches the conditions of language acquisition in the natural conditions of its existence.

The cognitive aspect of the goal of teaching a foreign language is associated with the formation of students ' broad understanding of the achievements of national cultures (their own and foreign) in the development of universal culture and the role of their native language and culture in the mirror of another culture. The formation of language consciousness is based on the General base of the primary human experience, on the basis of this experience, the cognitive core of the block of thought schemes of the individual cognitive system is formed, which is a constantly developing system of knowledge and beliefs of the individual. The level of cognitive (mental) models is built over the block of thought schemes. The basis of language consciousness is associative semantic networks, which by their nature are not linguistic, but cognitive.

Knowledge of another culture is carried out in the process of perception of another's national-specific "picture of the world", its interpretation with the help of images of their national consciousness. Specific fragments of an unfamiliar culture can be perceived as strange, alien, and unusual, and can cause sociocultural alienation or naive admiration for everything foreign. Teaching a foreign language is designed to reduce such negative aspects of cross-cultural communication.

When learning a foreign language, students should learn: world culture, national cultures and social subcultures of the peoples of the countries of the language being studied and their reflection in the way and style of life of people; the spiritual heritage of countries and peoples, their historical and cultural memory; ways to achieve intercultural understanding.

It is important that the formation and improvement of these skills are carried out in close relationship with the development of communication skills, with the work on various 
aspects of the language. Thus, the cognitive aspect of goals closely links foreign language teaching as a means of intercultural communication with intensive use of it as a tool for learning, development and language acquisition.

The ability to communicate at the cross-cultural level implies that a person has such personal qualities as openness, tolerance and readiness to communicate. Openness is associated with the ability of a person to tolerate the manifestations of alien, unusual in other cultures, readiness for intercultural communication, which are an essential component of communicative competence and provide active communication with representatives of other socio-cultural communities

The development of the ability to inter-cultural communication is associated with the development of students ' competence, which allows them to relate their culture to the culture of the country of the language being studied, and this requires the ability to see differences and commonalities in cultures, in the perception of their native speakers, in the systems of norms, duties, rights, etc., adopted in different societies

In modern society, which is characterized by the expansion of interstate relations, trade and economic ties with foreign countries, the development of science and technology, the constant exchange of scientific and technical information, the importance of a foreign language as an effective factor of socio-economic, scientific and technical and General cultural progress, as a means of oral and written communication between representatives of different peoples and cultures increases. The increasing role of a foreign language in the life of society and in the General education of young people is reflected in the practice of teaching it.

This can be scientific discussions in the language with the involvement of foreign specialists, reviewing and discussing fiction and scientific literature by a foreign woman, listening to individual courses in a foreign language, participation of students in international conferences, working as a translator.

It should be noted that with the expansion of the goals of teaching foreign languages, the requirements for the level of professional training of teachers are also increasing. In real life, the teacher is the main communicative partner of students.

Knowledge of the business culture of a country is a powerful factor for the successful conduct of business or other nature of business relations with a particular country. This issue is of significant importance for both future lawyers and future managers, since they will need all the knowledge, skills and abilities in intercultural communication that they have acquired in foreign language classes in their future professional activities.

An equally important point in the formation of readiness for intercultural communication in foreign language classes is to familiarize students with the basic principles of improving the effectiveness of intercultural communication on the language material. They are very simple. In written communication: avoid idioms, abbreviations, jargon, acronyms

In oral communication: you must speak slowly; do not interrupt the other person; avoid using slang and swear words; encourage feedback from the other person, or give comments; observe non-verbal signals. If you think that there is a misunderstanding, change your approach to the question. A modern lawyer or Manager should be able to solve problems of an international scale. They must have a professional culture, new thinking, free from stereotypes of the past, and cross-cultural communication skills

It is advisable to focus students ' attention from the very beginning on the significant differences in English and Russian in the lexical and grammatical ways of expressing polite treatment, requests, non-categorical statements, implicit requests, etc. This must be done before the influence of the native language will form the skills of incorrect use of modal verbs, imperative forms, explicit expression of negative evaluation.

Therefore, it is very important to choose the right textbooks and manuals for students. Tasks can be varied and changed in accordance with the tasks of forming cross-cultural competence. We should not forget that the culture of a foreign country should be studied in 
comparison with the native culture and show students both positive and negative aspects in each culture. The effectiveness of classes is significantly increased if they are held in the form of debates or role-playing games, where each student can reveal their abilities, show their knowledge, learn and most importantly, get involved in work, learn to think creatively and work.

$$
* * *
$$

1. Ageev, B. C. Intergroup interaction. - Moscow: Znanie, 1990. -180 p. 2. Andreev, V. I. Pedagogy of creative self-development Innovative course. Book 2. Kazan University Publishing house, 1998. -318 p. Babansky, Yu. K. Problems of improving the effectiveness of pedagogical research: Didactic aspect. - M., Pedagogy, 1982. $-192 \mathrm{p}$.

2. Vorobyov, G. A. Development of socio-cultural competence of future foreign language teachers (search for effective ways) / / Foreign languages at school. 2003. - no. 2. - Pp. 26-30. 